\title{
The rape law revision in Denmark: Consent or voluntariness as the key criterion?
}

\author{
JØRN VESTERGAARD * \\ "Consent and voluntariness are not (necessarily) identical concepts; however, \\ the basic questions are the same.» ${ }^{1}$
}

\section{Introduction}

The adoption of a consent-based rape provision in the Danish Penal Code has gradually gained sufficient political support. The overall objective behind the law reform is to render better protection of the right to sexual self-determination and sexual integrity. However, in the recent run-up towards a political agreement, a sharp dividing line has separated the proponents of change due to a heated controversy with regard to the choice of the term to be used in the revised criminal law provision, i.e., 'consent' or 'voluntariness'. The disagreement has caused a protracted deadlock in the reform process. This article examines the polarising opinions in the debate and compares the potential impacts of the debated models. It will be demonstrated that the demarcation line between the two opposing parties in the debate concerning the choice of the appropriate terminology has been drawn unnecessarily sharp. The reach of the amended rape legislation will not merely depend on the wording of the rape provision but will, at least in part, depend on the clarifications provided in the preparatory works. Ultimately, the courts will have to clarify the legal implications of

* Professor Emeritus of Criminal Law, Faculty of Law, University of Copenhagen.

Email: jv@jur.ku.dk.

1 Petter Asp, M.C. v. Bulgaria - a Swedish Perspective, Scandinavian Studies in Law (2009) pp.

191-211.

This is an Open-access article distributed under the terms of the Creative Commons Attribution 3.0 Unported License (http://creativecommons.org/licenses/ by/3.0/), permitting all use, distribution, and reproduction in any medium, provided the original work is properly cited. 
Jørn Vestergaard

an individual's passivity in a sexual encounter and address the adequate assessment of sexual encounters taking place against the backdrop of psychological violence and abuse.

\section{The shift in legal discourse: from 'use of consent' to 'voluntary consent'}

Defining rape as a violation of sexual autonomy has been the focus of attention for academics, gender equality activists, and politicians for a long period of time. The basic underlying premise in the debate reflects the idea that an individual has a right to make autonomous decisions about entering or not entering into sexual relations. The traditional perception of rape as a crime that requires coercion from the perpetrator and resistance by the victim has by many been considered as inadequate in a modern construction of the offence. According to feminist and other voices, voluntary consent by each participant in a sexual encounter must be a pivotal and conclusive factor, thus putting the protection of deliberate sexual choice at the centre. The practice of confronting rape victims with intrusive and intimidating questions about their sexual history should be abandoned. Victim blaming by public officials involved in investigating, prosecuting, and adjudicating rape cases should be avoided. ${ }^{2}$

No international or regional human rights instrument or commonly agreed standard provide for a substantive definition of consent to be applied in rape legislation. The Council of Europe's Istanbul Convention denominates the lack of consent as 'the key point of convergence' in modern rape law. ${ }^{3}$ The Convention prescribes that nonconsensual acts of a sexual nature should be criminalized. It further stipulates that consent 'must be given voluntarily as the result of the person's free will assessed in the context of the surrounding circumstances." However, in implementing the Convention's positive obligations, State Parties enjoy a considerable margin of appreciation. States are obliged to provide effective protection against rape and other sexual abuse by means of penalisation, effective investigation, and prosecution of any non-consensual sexual act, including in the absence of physical resistance by the victim. ${ }^{5}$ But it is for domestic legislators to decide on the specific design of

2 The literature on legislative reform initiatives with regard to the penalisation of sexual assault is vast. For a brilliant contribution, see Eithne Dowds, Towards a Contextual Definition of Rape: Consent, Coercion and Constructive Force, 83(1) The Modern Law Review (2020) pp. 35-63. For earlier developments in rape law reform, see Clare McGlynn \& Vanessa E. Munro (Eds.), Rethinking Rape Law: International and Comparative Perspectives (Routledge 2011).

3 Joanne Conaghan, The Essence of Rape, 39(1) Oxford Journal of Legal Studies (2019) pp.151182.

4 Council of Europe Convention on preventing and combating violence against women and domestic violence (Istanbul Convention), Art. 36, CETS 210 (2011).

5 See M.C. v. Bulgaria, appl.no. 39272/98, 4 December 2003, para. 153-166 in particular. 
the legislation and the factors that they consider precluding freely given consent. ${ }^{6}$

Applying the concept of consent in a legal setting requires some measure of qualification relating to the conditions under which acceptance by one individual of acts performed by another is considered to constitute a legally distinctive consent. ${ }^{7}$ At the core of the matter lies the difficulty in assessing situations in which an intimate encounter between partners, friends, or acquaintances, gives rise to grievance and perception of assault even in the absence of any traces of violence or resistance. Particular problems arise in situations where the aggrieved party sends mixed signals during the sexual act or even acts passively, especially due to the so-called frozen fright response. ${ }^{8}$ In such cases, the context of surrounding circumstances can be critically relevant in order to determine whether an individual's right to make a free choice has been constrained or encroached.

As a matter of general principle, an offence must be clearly defined in the law, so that an individual knows from the wording of the relevant provision - and, if need be, with the assistance of the courts' interpretation and with informed legal advice - which acts and omissions will make him criminally liable. ${ }^{9}$ In borderline rape cases, embedding the law in consent-based semantics inevitably gives rise to particular challenges with regard to maintaining a sufficient degree of legal certainty, coherency and consistency.

\section{Recent research on the impact of consent-based rape legislation}

Merely a limited number of countries have introduced rape laws that are explicitly consent-based. ${ }^{10}$ Even those laws are framed rather differently depending on the legal traditions in the various jurisdictions. Accordingly, the appropriate use of the concept

6 Explanatory Report to the Istanbul Convention, para. 193. Most legal scholars agree that the European Convention on Human Rights, as interpreted in M.C. v. Bulgaria, does not make it mandatory to have legislation according to which sex without consent is a sufficient requirement to establish the offence of rape. See e.g. Jørn Jacobsen, Valdtektsstraffebodet (Fagbokforlaget 2018) pp. $40 \mathrm{ff}$. However, various reform proponents still challenge this position by maintaining that in order to comply with obligations under international law, domestic legislation must be consent-based. See e.g. various policy statements by Amnesty International.

7 See Petter Asp supra note 1. For a more comprehensive analysis, see Asp, Sex och samtykke (Iustus Förlag 2010).

8 For a comprehensive and inspiring review of the trends in academic and judicial discourse, see Linnea Schmidt, How we talk about rape matters - the construction of rape in the Swedish legal system. Master Thesis (Lund University, Department of Sociology 2020).

9 The European Court of Human Rights has continuously reiterated this principle. See e.g. Vasiliauskas v. Lithuania, Grand Chamber, appl. no. 35343/05, 20 October 2015, para. 153-155.

10 See Amnesty International, Right to be free from Rape: Overview of Legislation and State of Play in Europe and International Human Rights Standards (2018). See also various reports by the European Institute for Gender Equality (EIGE), e.g., Analysis of the National Definitions of Rape (2016), and Glossary of definitions of rape, femicide and intimate partner violence (2017). 
consent, voluntary agreement, etc., has been of continuous concern to scholars. ${ }^{11}$ Thus far, no consensus has been reached in domestic legislation and academic literature regarding how to adequately define the legal elements of sexual consent. ${ }^{12}$

Academic studies maintain that following the introduction of consent-based legislation, certain aspects of traditional gender-based stereotypes and myths may still persist and influence both the general public and the legal discourse. ${ }^{13}$ The narratives underlying the significance of coercion and victim's resistance tend to permeate the criminal process, with police officers, prosecutors, lay assessors and judges still casting suspicion on complainants who did not physically or verbally resist. ${ }^{14}$

The different models of consent-based rape legislation have all been designed with a view of taking into account the 'profoundly messy contexts' within which sexual decision-making sometimes takes place. ${ }^{15}$ One way or the other, all consentbased laws reflect the notion that the protection of sexual autonomy requires an appreciation of a wide range of behaviours that may undermine self-determination and thus constitute rape. Ideally, the law must facilitate the discussion as to whether there was sufficient opportunity for the complainant to have a free choice and for the accused to acknowledge this. In other words, rape legislation must take into account the 'continuum of coercion' within which sexual assault may occur, by also covering situations in which apparent consent is not an expression of free and deliberate choice, but submission due to some kind of abusive circumstances and oppression.

A prominent recent study observed that current consent-based laws too often 'bolster the defendant's claims of belief in consent on the basis of the complainant's actions or inactions' rather than by exploring how the context and the accused's use of that context affected the complainant's ability to control intimate contact. In light of this, it is argued that 'a doctrine of constructive force' has the potential to direct attention to the perpetrator's use, abuse or creation of 'a coercive environment'. Instead of asking how the circumstances or the complainant's behaviour may have led the accused to

11 On the many controversies regarding interpretation of the rape legislation in England and Wales, see Catarina Sjölin, Ten years on: Consent under the Sexual Offences Act 2003, 79(1) The Journal of Criminal Law (2015) pp. 20-35, and Bethany Simpson, Why has the Concept of Consent Proven So Difficult to Clarify?, 80(2) The Journal of Criminal Law (2016) pp. 97-123.

12 For an elaborate account of consent-based legislation and rape case jurisprudence in England and Wales, and in Canada, see Dowds supra note 2. Jurisdictions such as Italy and Michigan, in which consent is implicitly considered as a relevant factor under 'coercion-based' legislation, are also dealt with in the article. See further Conaghan supra note 3.

13 Following the development in Swedish rape law, rather modest effects on court practice were recorded in the interesting study by Schmidt supra note 8. However, the author's findings indicate that courts no longer to the same extent require evidence of physical violence.

14 Dowds supra note 2, p.36. On the persistence of the 'real rape' stereotype, see Conaghan supra note 3.

15 Dowds supra note 2, p. 62. 
reasonably believe there was a consent, the pivotal question would be whether the accused was aware that the complainant's free will was restricted, and whether the accused had reason to believe that the complainant consented. ${ }^{16}$ Given that consentbased rape law continues to be developed and evaluated in various jurisdictions, this approach might serve as a source of inspiration. It may also prove to be beneficial in assessing the implications of the current law reform in Denmark as outlined below.

\section{The prelude to the introduction of consent-based rape legislation in Denmark}

Like in other countries, the introduction of a consent-based rape provision haslong been a key concern for a number of organisations, activists and professionals in Denmark. Finally, abroad politicalmajorityin favour of thelegislativeamendments has nowemerged.

Centre-left political parties endorsed the revision of the existing rape provision several years ago. In 2016, significant support materialised in a joint policy statement adopted by three party leaders. ${ }^{17}$ In an empathic declaration, they stated that too many victims are raped, too few rapes are reported, only few offenders are convicted, and sentencing is in many instances too lenient. Several important notions were conveyed in the statement. First, the legislative requirement that rape as a criminal offence presupposes the use of violence or threat is an indication that victims are often disregarded, and 'we fail to secure protection under the law'. Second, all sexual acts must be voluntary, and sexual acts without consent must be penalised. Third, a requirement of consent and thus protection of fundamental values, such as autonomy and equality, should be reflected directly in the legislation, so that the law clearly demonstrates everyone's responsibility to ensure that sexual acts only take place when the parties agree. Therefore, consent must be the central and decisive element of the crime. Fourth, the prelude to sexual activity should not be relevant in the assessment of evidence, e.g., whether the victim danced in a sexually provocative way or was dressed in a short skirt and stilettos. Finally, the party leaders declared that rape is never the victim's own fault.

Unsurprisingly, various objections were raised against the introduction of a consent-based model. The main opposition dealt with the risk of reversing the burden of proof in rape cases. Critics claimed that if a woman were to regret a sexual intercourse, the man involved would face conviction, unless he could produce

16 Dowds supra note 2.

17 Joint declaration by the party leaders from Socialdemokratiet, Radikale Venstre and Socialistisk Folkeparti, published in the daily newspaper Berlingske on 21 August 2016: http://berlingske.dk/ politik/roede-partier-vil-straffe-sex-uden-samtykke-som-voldtaegt. 
a written agreement or some other manifest documentation. ${ }^{18}$ In response, it was pointed out that a key feature of consent-based legislation is not that a defendant should prove consent, but that the prosecution must prove that there was no agreement, and that in this respect the accused met the liability standard required by law.

The Danish Parliament (Folketing) has tabled proposals to implement a new consent-based definition of rape three times since 2016. These legislative initiatives were premised on the notion that 'if not voluntary, sex is not sex but rape'. It was implied that voluntary consent could be inferred directly as well as indirectly from words or conduct. None of the three proposals won a majority.

In the wake of celebrating the International Women's Day on March 8, 2019, the then Minister of Justice ${ }^{19}$ announced that he had now been convinced by reports and statements from women advocating reform that it was high time to introduce 'a consent-based provision based on voluntariness'. Subsequently, the then Prime Minister ${ }^{20}$ also announced that his administration now favoured an amendment of the rape provision with voluntariness as a key component of an revised definition. The Prime Minister stated that 'voluntariness is an indication of consent'.

Subsequently, the Permanent Penal Code Committee (Straffelovrådet) was entrusted with the task of preparing proposals for new rape legislation. Generally, the Committee is vested with the responsibility for drafting recommendations regarding legislative matters at the request of the Department of Justice. The Committee members are senior officials representing the courts, the police, the prosecution, the Ministry of Justice, the Prison and Probation Service, the universities, and an experienced defence attorney.

Following the 2019 parliamentary elections, the centre-left parties gained a majority and consequently entered into a comprehensive political agreement under a so-called Declaration of Understanding, which formed the basis for a change of Government. ${ }^{21}$ The Social Democrats took office with the backing of three other parties as political allies. The Declaration included a brief section on the promotion of gender equality. The most specific part of the section pledged that the new administration would introduce legislation in order to enact a consent-based rape provision 'on the basis of the recommendations of the Penal Code Committee'. It was expected that a bill to this effect would be presented during the parliamentary session in spring 2020. However, due to

18 The terminology used in this article mirrors the statistical fact, that the majority of victims are women, and most perpetrators are men. However, under Danish law, the rape provision is gender neutral.

19 Mr. Søren Pape Poulsen, Chair of the Conservative Party.

20 Mr. Lars Løkke Rasmussen, Chair of the centre-liberal party Venstre.

21 Retfordig retning for Danmark. Politisk forståelse mellem Socialdemokratiet, Radikale Venstre, Socialistisk Folkeparti og Enhedslisten [Fair Direction for Denmark. Political Agreement]: https:// altinget.dk/misc/Retf\%C3\%A6rdig\%20retning\%20for\%20Danmark_2019-06-25_endelig.pdf. 
conflicting views on the wording and the substance of a revised provision, a stalemate occurred. In the following sections, the debate will be analysed, as well as a comparison between the anticipated impacts of the proposed legislative models will be offered.

\section{The present rape legislation under criminal law in Denmark}

The current Section 216 of the Penal Code (straffeloven) defines rape as the use of violence or threats of violence to accomplish sexual intercourse, or otherwise engage in sexual intercourse by means of coercion, or to have intercourse with someone who is in a state or situation in which that person is unable to resist the act'. The Penal Code's chapter on sexual offenses was extensively amended in 2013. That revision was based on a report produced by the Penal Code Committee.22 At the time, the Committee consisted entirely of male members.

The Committee's report included deliberations on whether coercion through violence should be retained as a defining criterion of rape, or whether the criminalisation of non-voluntary participation in sexual activities should reflect that the victim has not consented. Back then, the Committee maintained that criminalisation of the most serious sexual offences should still be based on the requirement of violence, coercion or abuse, and not on consent-based rules concerning non-voluntary participation in sexual activity. The Committee emphasised that there is no standard definition concerning the concept of consent. Thus, a sufficiently precise distinction between sexual offenses and acceptable forms of sexual conduct would not be achieved by introducing a consent-based rule. Under a consent-based model, the proof of guilt would still depend on evidence regarding violence or threats that could indicate the absence of an explicit or tacit consent. In light of this, the Committee found that consent-based legislation could not be expected to cover cases other than the criminal provisions requiring coercion already covered.

Furthermore, the Committee held that it would be difficult to transpose the traditional consent structure from the realm of contract and torts law to sexual offences. Ordinary sexual activity between adults is not characterised by the conclusion of agreements, elaborate deliberations or formalizing sexual activity in other ways.

'Among people who have not previously had sexual relations with one another, the activity will more often than not be characterised by the fact that one individual as an active party tries to get as far in the direction of the desired activity as the other party allows. A signal that one party does not want to engage in further sexual activity can be given before the other party has "gone too far" or immedi-

22 Straffelovrådets betænkning nr. 1534/2012 om seksualforbrydelser [The Permanent Penal Code https://elov.dk/media/betaenkninger/seksualforbrydelsesbetaenkningen_bind_1.pdf. 
ately after. In the latter case, a violation has in principle occurred, which the active party, however, hardly understood. Sexual relationships can sometimes also be characterized by one or both parties being under the influence of alcohol, which can hamper the ability to indicate the lack of consent to sexual intercourse, as well as the ability to read such signals.'

The Committee also turned down a proposal aiming at supplementing the existing coercion-based rape provision by introducing a subsidiary consent-based provision. In that context, the Committee offered the following argument with regard to cases where the aggrieved party is completely passive:

'If a defendant's claim that he perceived the distressed party's attitude as an expression of consent cannot be rejected in view of the sufficient certainty required for the proof of guilt, then he cannot be convicted on the basis of a provision requiring intent - and that would neither be the case for violating a provision prohibiting having sexual intercourse without consent. And if the defendant's explanation is disregarded and it is assumed that he acted with the required intent regarding the fact that the victim had not agreed, and the victim's passivity was caused by fear, then the defendant will be convicted of rape - not for violating a subsidiary provision regarding sexual intercourse without consent.'

\section{The Penal Code Committee's report on a voluntariness-based rape provision}

In February 2020, the Penal Code Committee's new report was published and submitted for public hearing. The report is entitled Report on a voluntariness-based rape provision. ${ }^{23}$

This time, the Committee was composed of eleven members: the President of the Supreme Court as Chairman, supplemented by an additional Supreme Court justice and a municipal court judge, the National Prosecutor General, a Police Constable, a Prison and Probation Service executive, the Research Director of a Public Sector Research Institute, a Head of Department of the Ministry of Justice, a defence attorney and two criminal law professors. Out of the eleven members, four are women. Only the Supreme Court Justice was a member of the Committee when its report on sexual crimes was presented in 2012.

23 Straffelovrådets betænkning nr. 1574/2020 om en frivillighedsbaseret voldtægtsbestemmelse, offentliggjort den 19. februar 2020 [The Permanent Penal Code Committee's report 1574/2020 on a rape provision based on voluntariness, published on 19 February 2020]: https:// justitsministeriet.dk/wp-content/uploads/2020/02/betaenkning_1574_final.pdf.[author's translation] 
The key concept in the Committee's mandate was 'voluntariness' (frivillighed). The task was to review the existing criminal provision on rape, focusing on whether the current legislation sufficiently reflects that participation in sexual activity must be voluntary. The Committee was tasked to analyse how a requirement regarding mutual voluntariness could be clarified by revising the wording of the provision. More specifically, the Committee had to consider how to define a voluntariness requirement, and clarify how the prosecution would be able to meet the burden of proof regarding non-voluntariness. Remarkably, the concept of consent did not feature at all in the Committee's mandate.

Prior to involving the Penal Code Committee in the current law reform process, the term 'voluntariness' had only been occasionally mentioned in the public debate on rape law. The term 'voluntariness' was used as synonymous with and supplementary to the term 'consent'. The abovementioned policy statement by the three political party leaders is a prominent example as to how the word 'voluntariness' was used rather casually.

For a long time, the calls for a rape law reform had embedded the concept of consent as the core mantra. This changed in light of the direction taken by the Swedish law reform, which came into force in 2018. The Swedish Criminal Code (brottsbalken) is now based on the concept of voluntariness: The term 'consent' is not explicitly mentioned in the Code, although the amended criminal legislation is often referred to as 'the consent law' (samtykkeslagen).

Given that the focus on the concept of consent gave opponents of reform a cause for rather strong and exaggerated remonstrance, the author of this article argued that it would be beneficial to look into the Swedish experience and introduce the concept 'voluntariness' as the key criterion of the new rape provision. This was suggested to facilitate the reform process and not to insist on a particular wording of the revised rape provision. ${ }^{24}$

\section{The Penal Code Committee's endorsement of the rape law reform}

The Committee's report starts with a brief account of the public debate on the subject. In addition, it describes the current state of the law, the rape legislation in ten other countries, and Denmark's international obligations in the given area. ${ }^{25}$

24 For an account of the debate in Denmark and the reform in Swedish rape law, see Jørn Vestergaard, Voldtægtsbestemmelse med frivillighed som omdrejningspunkt, Ugeskrift for Retsvoesen (2019) pp. 277-286.

25 For specific references to the Committee's report and the public debate, see Jørn Vestergaard, Voldtægtsparagraffen - frivillighed eller samtykke?, Juristen (2020) pp. 117-129. 
The report's annex includes a summary of 30 selected judgments that have been handed down since the beginning of 2017. Among these decisions, the Committee highlighted nine acquittals where fairness with regard to the principle of sexual self-determination was characterised as 'debatable. ${ }^{26}$ Five decisions were instances where the defendant was possibly aware that the sexual intercourse took place against the other party's will. However, the sexual activity was not intentionally enforced by violence or threats of violence. Four decisions concerned cases in which the victim did not persistently exhibit clear resistance through bodily response or utterance, but was not in a mental state or situation in which she was unable to do so.

In light of the reviewed case law, all Committee members found that the current law does not sufficiently protect everyone's unconditional right to sexual self-determination and sexual integrity. The Committee members unanimously agreed that the rape provision needed to be revised. They recommended for the term 'rape' to be retained. However, it should no longer be a decisive requirement whether the defendant exerted coercion or whether the victim was in a mental state or situation in which she was unable to resist the sexual intercourse. Instead, the focus should be shifted to whether the parties were 'in agreement' about engaging in the sexual activity. If violence or other coercive means were used, this should be considered as an aggravating circumstance of crucial relevance for the sentencing. The expansion of the law's reach was intended to aid in clarifying the scope of the criminal law protection and to mark society's dissociation from violations of sexual autonomy.

However, the choice of preferable terminology triggered tensions and disagreement among the Committee members. The overwhelming majority of the members adhered to the given mandate and recommended to integrate the concept of voluntariness into the definition of the rape offence. One member dissented by instead proposing to embed the criterion of consent into the new rape provision. ${ }^{27}$

Still, it was acknowledged by all the Committee members that neither 'voluntariness' nor 'consent' has a clear definition or well-established delimitation in the criminal law context. Putting terminology aside, it would be necessary to explain in greater detail what was meant in the preparatory works of the new rape provision.

In contrast to Swedish criminal law, the Danish Penal Code does not contain a general provision regardingconsentasalegaljustification. UnderDanish criminallaw, thepotential relevance of consent needs to be determined on a case-by-case basis in relation to the specific type of offence. Consequently, the Committee members agreed that there is no

26 The Permanent Penal Code Committee's report no. 1534/2012 on sexual crimes, supra note 22, pp. $125 \mathrm{ff}$.

27 The dissenting Committee member is Professor Trine Baumbach. Professor Thomas Elholm joined the Committee's majority. Both are Professors of Criminal Law at the University of Copenhagen. 
reason for concern regarding the use of the term 'consent' in an amended rape provision.

The Committee did not recommend introducing criminal liability for rape based on the mens rea of negligence. This runs contrary to the rape laws recently introduced in Sweden and in Norway. Rather, the Committee proposed to abolish the existing criminalisation of negligence in situations where a perpetrator did not realise that the victim was in a particular state in which she was unable to resist the sexual act. ${ }^{28}$ Given that both the voluntariness-based and the consent-based models are intended to introduce a stricter obligation to ensure that the participation in a sexual intercourse is voluntary, the amended rape provision will allegedly cover situations punishable under the current provision regarding liability for negligence. This line of argument was neither explained nor substantiated in the Committee's report, and it is not entirely convincing. However, there can be other valid reasons for not criminalising negligence with regard to the absence of consent to engage in sexual intercourse. Thus, the lack of a common normative yardstick for the assessment of negligence in such situations entails a serious risk of legal uncertainty.

The Committee unanimously proposed that the existing sentencing levels should be maintained for crimes that are punishable under the current Danish Criminal Code.

\section{The two proposed models for a revised rape provision}

The proposal by Committee's majority is inspired by Swedish criminal law and is formulated as follows: ${ }^{29}$

'Section 216. Anyone who has sexual intercourse with a person who does not voluntarily participate shall be punished for rape by up to 8 years of imprisonment.

Subsection 2. In order for participation to be considered voluntary, the choice to participate must be expressed through words or conduct, or be evident in the specific situation and context. There is no voluntariness if sexual intercourse has been enforced by violence or threats of violence. There is also no voluntariness if the perpetrator obtained sexual intercourse by employing other types of unlawful coercion, ... or involves a person who is in a state or situation in which the person is unable to resist the act.'

Depending on the particular circumstances of the case, psychological violence can implicate that a person's participation in a sexual intercourse was not voluntary.

28 The Danish Penal Code, Section 228.

29 Report 1574/2020 supra note 22, p. 174. [author's translation] 
The Committee's majority emphasised that the amended rape provision must be formulated as clearly as possible with foreseeable legal implications in order to enable citizens to comply with the law. In the majority's opinion, legal certainty can best be achieved by introducing a rape provision based on voluntariness. The majority did not elaborate further on this consideration, although it recognised that the proposed provision contains more discretionary elements than the current provision. In fact, the proposed provision does not encompass strict criteria comparable to those regarding the use of violence or threats. Thus, to comply with the legal certainty requirement and avoid a violation of the defendant's rights, the revised rape provision's preparatory works should offer adequate clarification.

Somewhat obstinately, the Committee's majority envisioned 'clear advantages and no significant disadvantages' in introducing a rape provision based on voluntariness, provided that the requirements of the requisite mens rea standard and the burden of proof remain unchanged.

The proposal presented by the Committee's minority is worded as follows: ${ }^{30}$

'Section 216. Anyone who has sexual intercourse with a person who did not consent to the act shall be punished for rape by up to 8 years of imprisonment. Consent must be given voluntarily as an expression of the person's free will taking into account circumstances of the specific situation. It shall be considered as particularly aggravating if the offence is accompanied by violence, threats of violence, psychological violence and other unlawful coercion, ... or involves a person who is in a state or situation in which the person is unable to resist the act.'

In the minority's view, a consent-based provision would ensure a clearer and more foreseeable state of the law than a voluntariness-based provision, and it would also give better safeguards to both parties' right to self-determination and personal freedom. ${ }^{31}$

The minority argued that the current legislation is basically premised on a requirement of non-voluntariness, and thus there is a need for a more distinct change by replacing the existing provision by a consent-based provision. In the view of the minority, the model proposed by the majority would merely entail a technical change that would not strengthen the criminal law protection of rape victims and would not ensure better prevention of the crime.

The Committee's majority maintained that the minority's interpretation of the content and reach of the majority's proposal was neither correct nor fair. The current legislation presupposed that the perpetrator has used specifically listed means of

30 Report 1574/2020 supra note 22, p. 187. [author's translation]
31 The clause regarding voluntariness is equivalent to Art. 36(2) of the Istanbul Convention. 
coercion or that the victim was in a state or situation where the person in question was unable to resist the acts. The model proposed by the majority would extend the scope of criminalisation to all non-voluntary sexual acts regardless of whether certain coercive means were used or whether the victim was in a particular vulnerable condition or situation. Thus, implementing the majority's proposal would not merely imply a formal change. This view is quite convincing.

The Penal Code Committee's report is loaded with a large number of more or less literal repetitions. Contrary to the drafters' intention, this does not help in facilitating an overview of the dividing lines between the positions of the two parties. The explanations and justifications for the two diverging proposals consist to a considerable extent of mutual criticism and reservations regarding the other party's line of argument. The following provides an overview of the two parties' views and arguments with regard to the core issues of the controversy.

\section{Explaining the majority's voluntariness-based proposal}

A guiding benchmark for the Committee's majority was that the concept of voluntariness 'best serves the intention' behind a new rape provision. The term 'voluntariness' emphasises that every individual has the right to sexual self-determination, and that every sexual act must be based on 'mutual voluntariness'.

In the opinion of the majority, it is intuitively understandable that sexual relations must be voluntary, while the concept of consent may indicate that some kind of formalised requirements must be met. Ordinary sexual activity between adults is not characterised by contractual agreements. Thus, an expressed requirement of consent could suggest a more extensive criminalisation than intended. This is the main reason given by the majority in favour of voluntariness as a key criterion rather than consent.

The majority further pointed to the fact that several other jurisdictions comparable to the Danish legal system have introduced rape legislation based on voluntariness, Sweden being a recent and prominent example. This can of course be a good reason for choosing such a design. However, consent-based models are in fact more prevalent.

Apart from what has already been mentioned here, the Committee's majority did not offer any substantial argument for drafting the proposed provision in a particular manner. The majority's choice of terminology is basically to be understood as an optout of a consent-based design.

As previously mentioned, the term 'voluntariness' actually appears in both of the proposals presented by the Committee's two conflicting sections. Understandably, neither the majority nor the minority endeavoured to clarify this key concept by providing a 
generic definition. The majority merely made a cursory remark that sexual intercourse can be considered voluntary if the involved individuals participate 'of their own free will'. The conclusive factor in that respect is that participants have had the opportunity to 'freely decide' whether they wanted to take part in the sexual intercourse. Whether voluntariness was actually present in a specific situation must be determined by a comprehensive and overall objective assessment of all the circumstances of the case, including evidence regarding the aggrieved party's utterances and conduct. ${ }^{32}$

Under all circumstances, verbal or physical resistance of another person's sexual advances should unconditionally imply that a subsequent sexual intercourse was non-voluntary. Thus, according to the majority's proposal, it would not be a legal requirement that the victim physically resisted the act.

The Committee's majority found that in 'many situations', it is necessary to impose an obligation on the person initiating a sexual intercourse to ascertain that the other party agrees. Still, it have to be taken into account that there are situations where there is 'a presumption of voluntariness' in light of the specific circumstances. In such situations, it is fair to expect that the other party indicates if she is not willing to engage in a particular type of sexual activity. If the rules are not designed to allow for such situations, there is a risk of penalising sexual conduct that many people consider as 'natural and customary'. The Committee's majority provided this argument in support of its proposition that the amended rape provision should be based on voluntariness rather than consent. This line of reasoning is hardly compelling, as the same reservation might very well apply to a consent-based provision.

In the opinion of the Committee's majority, an explicit expression of willingness to participate in sexual intercourse should not be a legal prerequisite for voluntariness. If two persons in 'an equal relationship' have had intercourse 'under ordinary circumstances', there would be a presumption of voluntariness even if one party was 'passive and unengaged'. However, the stipulated presumption was meant to be rebuttable.

Consequently, the legal effect of passivity should depend on the specific circumstances of the case, including the 'normal or extraordinary circumstances' under which the sexual intercourse took place, the course of events, the relationship between the parties, etc. The majority found such considerations more adequately covered by the concept of voluntariness than by the concept of consent. From a linguistic point of view, the argument is not really compelling, but rather an expression of choice.

32 As suggested above, inspiration for further qualification of these somewhat broad criteria could be drawn from 'the doctrine of constructive force', focusing on whether the accused was aware of or contributed to 'an environment of coercion' within which the complainant's free will was restricted. To that effect, see Dowds supra note 2. 
When voluntariness has not been expressed verbally or through bodily response, the particular circumstances of a sexual encounter should affect what an initiating party must be required to do in order to ensure that a passive party agrees, and when it is fair to expect the passive party to oppose the advances if she does not want to participate. This approach seems reasonable and is not far apart from the view of the minority, which will be discussed below.

When assessing the evidence of a specific case, the court must consider whether passivity was an expression of inability to resist. Accordingly, if an individual were 'strongly affected by fatigue, intoxication, etc.', it should be a manifest responsibility of the initiating party to make sure that participation in the sexual encounter was voluntary. In those circumstances, passivity would not constitute an expression of voluntariness.

The victim could also have been in a situation where she was physically able to defend herself but was taken by surprise and did not have a real chance to respond until the perpetrator had initiated sexual intercourse. Such violations can occur in connection with medical examination, massage, etc., where sexual advances are not normally to be expected. In such instances, it should be an obligation for an initiating party to ensure that the other person agrees to sexual intercourse. In the absence of such agreement, the intercourse should be considered non-voluntary.

If the aggrieved individual found herself in a state of instinctive fear and was therefore passive, because she 'freezed', 'ran on autopilot' or even tried to accommodate the perpetrator (freeze response, dissociation, tonic immobility), her involvement in the sexual activity was objectively non-voluntary. However, in such cases of a victim's impaired physical capabilities, the courts are confronted with difficult problems regarding the assessment of the mens rea on the part of defendants who claim that they perceived the other party's participation as voluntary.

In order to illustrate how to assess whether or not passivity is an expression of voluntary conduct, the Committee's majority drafted a hypothetical case. ${ }^{33}$ After a night on the town, two individuals went home to one party's flat. They voluntarily took off their clothes and laid down in the same bed. No discomfort had occurred between them during the preceding events. One of them initiated sexual intercourse. The other remained 'completely passive'. If the overture to the sexual intercourse could be characterised as sexually charged based on the specific assessment of the parties' preceding verbal and physical interaction, etc., the legal presumption would then be that the sexual intercourse was voluntary. In such a situation, the passive party must state that she does not want not participate in the intercourse in order for it to be considered as non-voluntary. In the given example, it was presupposed that the situation and the passive party's mental and physical state made it possi- 
ble for her to refuse, and the presumption regarding voluntariness was rebuttable.

The case presented by the Committee's majority is somewhat stylised, as it does not leave room for additional nuances that might be of importance in the evaluation of evidence in an actual criminal trial. It can give rise to doubt and misunderstanding as to what is meant by one participant being completely passive. The majority's assessment of the hypothetical scenario has been challenged by some of the participants in the public debate (see further below).

The Committee's majority rightly emphasised that the meaning of voluntariness and consent largely overlap. The minority disagreed. However, even according to the minority's proposal, consent does not have to be explicit or affirmative, but can be tacit or implied (see more below). Consequently, there is no real difference between the implications of utilising either 'consent' or 'voluntariness' as the key term. Regardless of the rape provision's wording, the task of the prosecution would be to prove that one party was not 'in agreement' about engaging in sexual intercourse.

Nonetheless, the Committee's majority explicitly acknowledged that in certain types of cases, especially those involving a victim's passivity, the two proposed models could lead to different outcomes. Depending on how the consent-based provision is designed, an initiating party might have a more extensive obligation to ensure that the other party agrees to sexual intercourse when compared to a voluntariness-based provision. Thus, passivity may indicate the lack of consent in situations where it remains a 'more open' question whether passivity is an expression of non-voluntariness or voluntariness. This rather vague, and in essence needless, concession to the minority's point of view has not facilitated the debate in a constructive manner. It is not at all evident that the state of the law will be dependent on the chosen terminology. In order to clarify this matter, the following section will focus on the implications of the minority's consent-based proposal.

\section{Explaining the minority's consent-based proposal}

For the Committee's minority, it was imperative that the 'duty of clarification' should not 'lie with the victim alone', in particular in certain instances of passivity. A person initiating sexual intimacy must always have a duty to ensure that the other party wants to participate. An individual should not have to 'say no' in order to avoid unwanted sexual activity but have to 'say yes' if she agrees to have sex. Consequently, the minority found it necessary to choose the term 'consent' as the constitutive element of the definition of rape.

The argument in favour of the consent-based approach is best illustrated by the minority's objections to the voluntariness-based provision: 
The Committee's minority claimed that voluntariness points 'in the direction of one's fulfilment of the other's desire. Consequently, the absence of resistance could make sexual intercourse voluntary. By merely altering the rape provision to a 'non-voluntariness' provision one would still place too much emphasis on whether the victim resisted and actively 'said no'. Thus, in some cases, the duty of clarification would lie solely with the aggrieved party and not the person who wants to engage in sexual intercourse. ${ }^{34}$ From a linguistic point of view, there is no solid support for such line of reasoning.

Even manifest consent can be offered coercively in order to comply with another person's wish. For this reason, the minority's draft model included the above-cited addendum in line with the Istanbul Convention. A valid consent must have been given 'voluntarily as an expression of the person's free will considering circumstances of a specific situation'. However, for the Committee's majority it was seen as an argument in favour of anchoring the rape provision in voluntariness as the core concept, that it was proposed by the minority to include exactly this term in a consent-based provision. Still, it is conceivable that a requirement of both consent and voluntariness may result in a more sharply delineated state of the law than a sole requirement of voluntariness. ${ }^{35}$

The Committee's minority conceived consent as 'something mutual' and 'a common desire' to have sexual intercourse. The minority maintained that under a consent-based provision, the relevant issue of proof would concern the actual presence of consent rather than the absence of an agreement. A consent-based rule would necessitate that each party agreed to have sexual intercourse. Consequently, anyone who initiates sexual activity becomes bound by the duty of clarification. Therefore, it was alleged that a consent-based provision would change the present evidentiary focus. The question would be whether the complainant consented and whether the accused had reason to believe that the victim agreed to the other party's sexual advances.

In the minority's opinion, the choice between voluntariness and consent have crucial bearing on the question of proof. The main difference is whether it is necessary to prove something positive (was there consent?) or to prove something negative (was there non-voluntariness?). In other words, the minority claimed that there is a difference between proving what the defendant did not realise (that the victim did not voluntarily participate in sexual intercourse) and what the defendant had reason to believe (that the victim consented).

However, the Committee's majority rightly pointed out that in any case the prosecution will have to prove that there was neither voluntariness nor consent. In both instances,

34 Report 1574/2020 supra note 22, pp. 16, 139, 168.

35 Such qualifying requirement points in the direction of the criteria embedded in the previously mentioned 'doctrine of constructive force'. 
evidence will have to be provided regarding the absence of something, i.e. the absence of voluntariness or the absence of consent, respectively. Concerning the issue of proof, there is no procedural difference with respect to the evidentiary focus. In a sense, the Committee's minority acknowledged this by stating that a consent-based rape provision will not change the presumption of innocence and thus will not alter the burden of proof.

\section{The potential differences between the proposed models}

Both the majority and the minority of the Penal Law Committee were preoccupied with the scope of the obligation to 'ensure' that any party in a sexual encounter has agreed to the activity. The majority held that such a duty should apply 'in many situations'. However, there are instances where there ought to be 'a presumption of voluntariness', as it is fair under certain circumstances to expect that the other party indicated that she did not agree to sexual intercourse.

According to the majority's draft provision, the choice to participate in sexual intercourse had to be 'expressed through words or conduct' or 'be evident in a specific situation or context' in order for participation in sexual intercourse to be considered voluntary. When engaging in the sexual activity, voluntariness can be conveyed in various ways, but there will rarely be a manifestly expressed agreement. Typically, the involved individuals will implicitly reach a common understanding that they both agree to sexual intercourse, e.g. by touching, kissing, etc., during the prelude to such intercourse.

In the opinion of the Committee's minority, a person who initiates sexual intercourse should 'always' be under an obligation to ascertain that the other person wants to participate. However, whether participation in sexual intercourse can be considered consensual will depend on a 'specific and comprehensive assessment' of the particular circumstances of each case. Thus, the minority's proposal did not require consent to be 'expressed directly or otherwise in a particular way' but depended on a 'completely informal' assessment. In accordance with the general criminal law doctrine, consent does not have to be affirmative, but can be tacit or implicit. In light of this, it is very difficult to understand what the difference between the two proposed models may turn out to be in reality.

Further, the Committee's minority stipulated that mutual consent would imply a 'desire' from each participant to take part in the sexual encounter. However, the minority appears to be in line with the majority on this issue, too. Wisely, the minority did not insist on attributing the decisive meaning to whether or not the distressed party participated in the sexual activity in accordance with her 'inner conviction'/ 'inner desires'.

The view presented by the Committee's majority on this issue was that participation is voluntary if a person who does not wish to enter into sexual intercourse never- 
theless 'chooses' to go along with it. This can be the case if one party in a marital relationship does not want sexual intimacy but agrees to it in order 'to accommodate' her spouse. The minority actually followed the same line of reasoning but in relation to the proposed consent-based requirement. Evidently, both the majority and the minority presupposed that there was no display of violence or threats involved in the specific situation. Consequently, there is no substantial difference between the two positions on this point, as they both accepted that even consent given reluctantly might nevertheless be considered as a valid consent.

As for the significance of preceding flirtatious behaviour or the fact that one party voluntarily went home with the other party, the majority and minority were essentially on the same line, too. All Committee members appear to agree that such conduct should not in itself be regarded as a sexually implicit prelude to sex. Nevertheless, both the majority and minority argued that their proposed model was best suited to take such circumstances into account. In particular, the majority claimed that a consent-based model could make it more difficult to conclude that the hypothetical case presented by the majority should not result in a rape conviction (as discussed above). The minority, on the other hand, believed that consent should 'more unambiguously' relate to the actual intercourse as such, while not taking into consideration the preceding events. Both positions are scarcely substantiated.

According to both proposals, the assessment of situations characterised by intimidation, e.g. sexual assault taking place in a dimly lit backyard or in a public toilet, should depend on the specific circumstances, and the models appear to be leading to the same conclusion. For the majority, there was 'no presumption of voluntariness' in such instances. The same approach applied to situations where acquaintances of the initiating party were present during the sexual encounter, or if a third party without prior agreement took photographs or recorded footage of the sexual activity. In such situations, silence or inaction of a distressed party would not suffice to indicate voluntariness. It was recognised that if sexual intercourse takes place in circumstances where the individual is or can be frightened, it can be particularly difficult to 'speak out' and say no. In such situations, passivity could be an expression of fear and not of voluntariness. The risk that a state of fear occurs is immanent in cases where there has not been a previous equal relationship between the parties. The risk may also be manifested in situations where the parties know each other, i.e. if the presence of others can be perceived as threatening and dangerous, or where the circumstances are suddenly significantly different from previous encounters. ${ }^{36}$

The Committee's minority noted in general that when assessing 'total passivity', there is 'a presumption that the victim does not consent'. The majority and the minority

36 These considerations by the Committee's majority fit well with the abovementioned 'doctrine of constructive force'. 
also seem to have had convergent views regarding the importance of one party being 'cheated' through misleading allegations concerning the use of contraceptives or regarding the other party's status or position. Engagement in sexual activity under such circumstances should not be considered as rape.

Moreover, both the majority and the minority presupposed that both parties in a sexual relationship must agree 'throughout the intercourse' for the entire activity to be voluntary.

Basically, it was a common starting point for all members of the Penal Code Committee that the two debated concepts from a legal perspective cover neither more nor less than what might be stipulated by the lawmaker in the preparatory works. In other words, the delimitation of the rape provision is not directly dependent on whether 'voluntariness' or 'consent' is used as the operative term.

With regard to the burden of proof, both parties emphasised that the models proposed by them would not entail any changes to the current state of the law regarding the presentation and assessment of evidence to the detriment of the complainant. The minority rightly pointed out that since there is currently 'a distinct focus on the victim's conduct', the shift in the evidentiary focus may even lead to a less burdensome presentation of evidence for complainants. The minority further emphasised that a consent-based model would not affect any legal guarantees for the accused.

\section{Reactions to the Penal Code Committee's report}

The public debate that followed the publication of the Committee's report has been accompanied by confusion regarding what the two proposed models would actually entail in practice, and in which situations they might lead to different outcomes. The presentation of the two positions has been far from accurate. Media coverage has reflected considerable uncertainty as to what the difference between choosing 'voluntariness' or 'consent' as the key concept would actually be.

Early on, the debate took a rather surprising turn. The main proposals in the report had been leaked to certain interested parties participating in the public discourse on gender issues and legal policy. The report was officially presented by the Committee Chairman to the Minister of Justice ${ }^{37}$ on 19 February 2020. The Minister invited the press to an afternoon briefing. Even before the presentation, various comments appeared in the social media and on the internet accompanied by numerous statements from Amnesty International, women's organizations and other actors who responded swiftly with resolute abandonment of the majori- 
ty's proposal and overwhelming support for the minority's recommendations.

During the press briefing, the Minister of Justice was confronted with the issue of disagreement among the Committee members. He responded that it was not decisive for him 'what we call it - the crucial matter is that we criminalize sexual acts that are not voluntary for both parties. ${ }^{38}$

In a parliamentary session, the Prime Minister took the opportunity to explain the government's considerations: ${ }^{39}$

\begin{abstract}
'Bruises and the ability to resist must not determine if rape has been committed. It is important that we introduce legislation reflecting that any sexual act can only take place if the involved parties agree to participate. Therefore, the Government will present a bill based on consent as agreed to in the Declaration of Understanding [agreed to by the centre-left wing parties]. Of course, we would like to discuss the details of the bill with the parties in Parliament, so that we are sure that we are on target as far as possible. It will be a milestone in the struggle for a more equal Denmark. What forms the basis for the Declaration of Understanding - which we will loyally adhere to - is consent. This is what the four parties have agreed to. Now we have received the report from the Penal Code Committee, which puts more emphasis on voluntariness. Naturally, it is reasonable to hear what they say, and it is also reasonable to consult input during the hearing phase...'
\end{abstract}

The Prime Minister's statement did not convey a crystal clear and definitive position on the choice between the concepts voluntariness and consent. However, her statement was interpreted as a commitment to choose the term 'consent' over 'voluntariness'. Against this backdrop, several actors consulted in the hearing process expressed their frustration regarding that a political choice had apparently already been made before the hearing phase had been completed.

\title{
13. The public debate concerning the proposals in the Committee's re- port
}

The release of the Committee's report led to a public exchange of rather pungent opinions. By that time, most of the substantial opposition to a revision of the rape law had vanished. Instead, the debate started spinning around divergent

38 https://nyheder.tv2.dk/politik/2020-02-19-politisk-enighed-om-aendring-af-voldtaegtslovmen-et-ord-deler-vandene.

39 Ms. Mette Frederiksen, Member of Parliament for The Social Democrats, Q\&A session, 25 February 2020: https://www.ft.dk/forhandlinger/20191/20191M065_2020-02-25_1300.htm. [author's translation] 
preferences regarding the wording of the prospective rape provision. Similar to the internal discussions between the members of the Committee, the public controversy centred on the choice between 'voluntariness' and 'consent. ${ }^{40}$ The contributions to the debate demonstrated a widespread tendency to misread the two proposals, thus exaggerating the differences regarding the anticipated reach of the law. This semantic disagreement has caused considerable turbulence and confusion, derailed the public discourse and slowed down the progress of the reform.

Fundamentally, some supporters of a consent-based model demand a legally indispensable requirement of affirmative consent. ${ }^{41}$ These participants in the public debate adhere to a strict interpretation of what should be required of a consent, i.e. there should be 'a positive indication' of the desire to have sex. According to both proposals by the Penal Code Committee, consent must not necessarily be given explicitly, but may be tacit or implied. Consequently, the decisive factor in assessing the issue of liability in a specific court case hardly depends on the wording of the provision. In some hard cases, the practical issue for the prosecution will more likely be the difficulty in meeting the burden of proof. In particular, it might be difficult for the prosecution to substantiate a plea that the parties in a relationship have not been sufficiently equal relating to the exercise of their right to self-determination.

Some commentators argued that what separates voluntary sex from sexual assault is 'passion'. ${ }^{42}$ The absence of 'signals concerning passion, e.g., continuous active engagement' should be an indicator of the absence of a valid consent to the sexual activities all along the way. Although such reflections are definitely relevant in the sexual ethics discourse, they are poorly suited to form the basis for rape legislation.

Several commentators found it problematic that the Committee's majority wanted to allow for the prelude to a sexual intercourse to be taken into consideration in the overall assessment of whether the participation in the sexual act was voluntary. ${ }^{43}$ As mentioned before, both the Committee's majority and the minority acknowledged that flirtatious conduct or the fact that one party went home with the other party could not in itself be considered as a sexually explicit agreement to have sexual intercourse.

It provoked particularly strong sentiments that the Committee's majority found it of

40 For references to the public contributions to the debate, see Vestergaard 2020 supra note 24, pp. 117-129.

${ }^{41}$ This position has been maintained in a hearing statement by Amnesty International Denmark: https://amnesty.dk/hoeringssvar-mv/hoeringssvar-forslag-til-samtykkebaseretvoldtaegtsbestemmelse

42 See hearing statement by Det Nationale Voldsobservatorium under Kvinderådet: https://kvinderaadet.dk/voldsobservatoriets-hoeringssvar-om-samtykkebaseretvoldtaegtsbestemmelse.

$43 \quad$ Ibid. 
crucial importance to avoid the risk of criminalising sexual behaviour that 'many' consider as 'natural and ordinary'. In reaction to this notion, leading reform proponents categorically distanced themselves from the concept of voluntariness per se. Amnesty, Everyday Sexism Project Danmark, and other NGOs insisted on this perspective. As previously noted, the majority's disclaimer represents a rebuttable presumption. It must therefore be understood as a point of departure for the judicial assessment of situations where individuals in 'an equal relationship' have sexual intercourse 'under normal circumstances', and one participant is 'passive and unengaged.' Nevertheless, some critics interpreted the reservation as an indicator that in close relationships there would be impunity for an individual engaging in the sexual activity with a passive spouse or partner who submitted due to psychological violence.

In the assessment of evidence, both the current law and the Committee's proposals require proof beyond reasonable doubt that the accused adequately recognised that the other party's participation in sexual intercourse was not voluntary. The Committee's majority posited that this issue must to be decided on the basis of an overall assessment of the specific circumstances, including whether there was a sexually charged prelude to the sexual intercourse. The minority maintained that in many instances such a model would lead to acquittal, whereas a consent-based provision would make it more obvious that the agreement must concern sexual intercourse itself. However, since the minority recognised that consent could be tacit and implied, it is doubtful that the specific assessment of evidence would differ from that under the model proposed by the majority.

In the Committee's report, as well as in the public discourse, the concept of 'passivity' has been utilised as a denotation for very different situations. This has muddled the debate, as various situations do not necessarily have to be assessed in the same way. The common feature of such instances is merely that an aggrieved party did not actively express her wish to participate in certain sexual activity but did not oppose the course of events neither physically nor verbally. Some proponents of a consent-based model have expressed themselves in very broad terms on the subject of the relevance and consequences of passivity, which blurs the discussion concerning the assessment of different types of situations. However, others have more specifically referred to certain groups of vulnerable individuals who are particularly in need of legal protection.

A particularly important group of cases is those in which the aggrieved party suffers from an unconscious state of fear and therefore is not able to resist, instinctively stiffens, and remains passive (freeze response). Such a situation is covered by the current rape provision, as well as by each of the models proposed by the two sections of Penal Code Committee. Both proposals presented in the Committee's report allow for a context-sensitive assessment of the evidence, recognising a wide range of trauma responses that victims of sexual abuse may exhibit.

Particular attention should also be devoted to the plight of victims suffering from sys- 
tematic humiliation and pervasive intimidation in a domestic setting, including instances of power asymmetry where one is in control over a partner due to informal coercive dynamics. A relationship marked by physical, emotional or psychological abuse can fundamentally affect an individual's sense of what options are realistically available to him/her. Consequently, the context of such circumstances can force the victim into a pattern of subordinate and compliant behaviour that can be perceived as voluntary participation, despite the fact that explicit threats and display of violence are unnecessary for forcing the victim into acquiescence and sexual submission. Some commentators maintain that such instances of sexual exploitation will not be considered as rape under the voluntariness-based model. ${ }^{44}$ This is actually not correct. Passivity due to psychological violence is not excluded from the reach of the design proposed by the Committee's majority. On the contrary, the majority explicitly pointed out that participation in sexual intercourse might be considered non-voluntary as a consequence of psychological violence. With regard to cases characterised by physical and psychological violence, the Committee's majority set up a legal presumption that the aggrieved party's participation in the sexual activity was neither voluntary nor consensual.

Some supporters of a consent-based model have fiercely advocated that the new rape law should apply without reservation to cases concerning compulsive everyday 'humdrum sex' involving cohabiting couples in long-term relationships when only one of the spouses actually wants sex and the other one merely submits. By contrast, some supporters of the voluntariness-based model have expressed exaggerated concerns regarding the boundaries and significance of the consent-based provision. Thus, the consent-concept has been met with the objection that a civilised society should not criminalise normal conduct between adults, including instances where none of the parties finds it necessary to obtain an explicit consent while engaging in sexual activity. ${ }^{45}$

Evidently, effective enforcement of the amended rape provision and adequate attention to the needs of victims do not only depend on the design of the law. Notably, considerable efforts have been vested in developing and implementing measures of a more practical and tangible nature. ${ }^{46}$ In particular, certain improvements have been achieved regarding police investigative work, legal representation for victims, etc. Yet, recent research confirms that in many reported rape cases women are still left frustrated with the performance of law enforcement officials. ${ }^{47}$

44 Hearing statement by the association Lev Uden Vold: https://levudenvold.dk/aktuelt/nyheder/ ny-samtykkebaseret-voldtaegtslov-samtykke-skal-gives-lobende.

45 An interesting case is presented by Jacobsen \& Sinding Aasen supra note 10, pp. $106 \mathrm{f}$.

46 On 12 December 2019, a range of recommendations was announced by the expert panel established by the Ministry of Justice. The panel includes participants representing the management of crisis centers for battered women, etc.: https://www.justitsministeriet.dk/ pressemeddelelse/ekspertpanel-vil-loefte-indsatsen-mod-voldtaegt.

47 Politiets tryghedsundersøgelse (2019) [Annual report on public safety by the Police]: https:// politi.dk/rigspolitiet/nyhedsliste/ny-tilfredshedsundersoegelse-giver-panderynker/2020/05/19. 


\section{The future state of rape law in Denmark}

Following years of a long-winded debate regarding the introduction of consent-based rape legislation, political support for amending the existing law finally materialised in the autumn of 2019. For one year more, the wording of the rape provision and the question regarding the reach of the law continued to be subject to discussion.

In continuation of the protracted maturation process, the centre-left parties finally entered into a political deal regarding the main characteristics of revised rape legislation in September 2020. Accordingly, a draft proposal reflecting the agreement was introduced by the Minister of Justice. A hearing process was concluded by the end of October 2020, and a formal bill was presented to the Parliament two weeks later. ${ }^{48}$ None of the hearing statements made a significant impact on the bill.

The wording of the Government's proposal for the new rape provision is short and simple:

'Anyone who has sexual intercourse with a person who did not consent to the act shall be punished for rape by up to 8 years of imprisonment.'

Without much further discussion, Parliament adopted the Bill by unanimous vote on 6 December $2020 .{ }^{49}$ No further explanatory comments had then been presented. The entering into force of the amended rape legislation was set to 1 January 2021.

It would have been somewhat startling, if Parliament had unconditionally favoured the proposal presented by the Penal Code Committee's minority with complete disregard of the considerations and recommendations presented by the Committee's majority represented by senior legal professionals from nearly all branches of the criminal justice system. However, that is not what has happened.

As suggested by the minority of the Penal Code Committee, the concept of consent has been applied as the key criterion. But, the proposed legal qualification regarding context-sensitivity is not stated in the actual provision. The requirement that consent must be given voluntarily as an expression of the person's free will considering the circumstances of a specific situation has been relegated to an explanatory note. Further, aggravating circumstances are not included in the revised provision, in contrast to the recommendation of the Committee's minority. By not utilising directly any

48 Lovforslag L 85 af 11 november 2020 til lov om ændring af straffeloven (Samtykkebaseret voldtogtsbestemmelse). [Proposal for amending the Penal Code (Consent-based rape provision): https://ft.dk/samling/20201/lovforslag/185/index.htm. [author's translation]

$49 \quad$ See link supra note 49. 
of the proposals offered by the divided Committee, the Government and its political allies may have wished to indicate an attempt to strike a delicate balance, while demonstrating the minimum degree of deference to both sections of the Committee.

Even though the politicians have choosen the word 'consent', some guidance has been found in the majority's analysis of the appropriate reach of the criminalisation. However, that course has been pursued without disregarding the views and concerns of the minority. The achieved convergence reflects that the proximity between the two proposals is more evident than featured in the debate.

The Committee's majority assumed that voluntariness might be inferred from the circumstances of the specific situation and context, and therefore it does not have to be an explicit statement. The Committee's minority emphasised that each participant in sexual activities has an obligation to ensure that the other party is comfortable with what is going on throughout the intimate encounter. The initiating party's responsibility in this respect is particularly urgent in cases where there is reason for doubt. Still, the minority accepted that the existence of consent can be assessed completely informally and thus may be tacit, which means the same as the conception presented by the majority. Thus, no material difference in positions is obvious.

\section{Conclusion and implications}

The fundamental purpose behind revising the rape provision is to safeguard the right to sexual self-determination and sexual integrity. The dividing line between the opposing parties in the debate over the choice of the appropriate wording has been unnecessarily sharp. The differences can be bridged, notwithstanding the terminological preference.

This article has demonstrated that the choice between the terms 'consent' and 'voluntariness' as the semantic anchorage point for a revised rape provision is not crucial in order to enhance the right to sexual autonomy. The future state of the law is not dependent on the actual wording of the new rape legislation but depends, at least to some extent, of how the legislator's intentions have been amplified in the preparatory works.

Some have argued convincingly that a consent-based rape provision will send a stronger signal with regard to the protection of the right to sexual self-determination, sexual integrity and personal freedom when compared to a voluntariness-based concept. The proponents of a consent-based model, including the Penal Code Committee's minority, have also maintained that a voluntariness-based provision would blur the state of the law and leave citizens uncertain with regard to the legal bound- 
aries of the legislation, and would therefore entail an unnecessary risk of violations. ${ }^{50}$

Regardless of the chosen terminology, issues concerning the assessment of evidence will still arise in cases where the complainant and the defendant present conflicting accounts of events. The Penal Code Committee did not examine in any detail what a revised rape provision might entail with respect to evidentiary challenges. The focus will no longer be determined by something that may have existed (violence, coercion, vulnerable condition or special situation), but by something that did not exist (lack of consent). Given that many rape cases are characterised by conflicting accounts as to what has actually happened, there is a reason for concern that judgements will increasingly be based on an assessment of the credibility of each party. In line with the previously mentioned 'doctrine of constructive force', the evidence assessment process could be significantly improved by systematically directing the focus of attention to the accused's use, abuse or creation of 'a coercive environment'. This approach is capable of adequately catching objective situations that are not covered by the current law.

The Penal Code Committee's members criticised acquittals in previous jurisprudence where sexual intercourse had been accomplished against the aggrieved party's will but was not deliberately enforced by violence or threats of violence. Another point of criticism concerned cases in which the victim did not manifestly resist, even though she was not unable to avoid the incident due to a legally qualifying condition or situation. Under the 'doctrine of constructive force', the appearance and performance of the complainant and the accused in court might become less important, as the essential question would be whether the accused was aware that the complainant's free will was restricted, and whether it was reasonable for him to believe that there was a consent..$^{51}$ Hence, inspiration for the further demarcation of the criminalisation of rape can be drawn from the abovementioned academic works. ${ }^{52}$

The robust legal framing of the new consent-based rape provision may be well suited to facilitate the promotion of respect for sexual autonomy by sending an easily conceivable message to the general public. However, the explanatory notes to the amended legislation are somewhat brief. Further guidance concerning the intended reach of the widened criminalisation is needed to attain an appropriate measure of legal certainty. In particular, there remains a troubling uncertainty concerning the legal implications of an individual's passivity in a sexual relation, and regarding the assessment of situations indicating a backdrop of psychological violence and abuse. It is now left

50 To this effect, see hearing statement by the Danish Institute for Human Rights, 13 March 2020: https://menneskeret.dk/sites/menneskeret.dk/files/media/document/H\%C3\%B8ringssvar\%20 over $\% 20$ udkast $\% 20$ til\%20forslag $\% 20$ til $\% 201$ ov $\% 20$ om $\% 20 \%$ C3\%A6ndring\%20af\%20 straffeloven\%20\%28Samtykkebaseret\%20voldt\%C3\%A6gtsbestemmelse\%29.pdf.

51 Dowds supra note 2.

52 See for example contributions by Jacobsen \& Sinding Aasen supra note 10, Sjölin supra note 12, Simpson supra note 12, Dowds supra note 2, and Schmidt supra note 8. 
Jørn Vestergaard

to the courts to develop a more or less stringent doctrine in rape law jurisprudence. 